The Original by FUNPEC-RP

\title{
Lack of differences in the expression of the angiotensin I - converting enzyme gene in the rotator muscles of patients with adolescent idiopathic scoliosis in a cross- sectional study comparing between the concave and convex sides of the scoliosis.
}

\author{
M. Wajchenberg ${ }^{1,2}$, D.E. Martins ${ }^{1,2}$, R.P. Luciano ${ }^{1}$, R.C. Araujo ${ }^{1}$, \\ B. Schmidt ${ }^{1}$, A.B.S. Oliveira ${ }^{1}$, E.B. Puertas ${ }^{1}$, S.S. Almeida ${ }^{1,2}$ and \\ F. Faloppa ${ }^{1}$ \\ ${ }^{1}$ Universidade Federal de São Paulo, Departamento de Traumatologia e \\ Ortopedia, São Paulo, SP, Brasil \\ ${ }^{2}$ Hospital Israelita Albert Einstein, São Paulo, SP, Brasil \\ Corresponding author: M. Wajchenberg \\ E-mail: marcelow@einstein.br
}

Genet. Mol. Res. 18 (2): gmr18246

Received November 14, 2018

Accepted April 08, 2019

Published April 30, 2019

DOI http://dx.doi.org/10.4238/gmr18246

\begin{abstract}
Several theories have been proposed to explain the etiology of adolescent idiopathic scoliosis (AIS), but none is conclusive. One such theory suggests the primary involvement of muscles due to myopathy, mainly affecting the erector and paravertebral rotator muscles. Studies indicate that there may be an association of AIS with genetic polymorphisms previously associated with physical performance and muscle power through their effects on muscle tissue. One of these is the gene coding for the angiotensin converting enzyme (ACE). We compared the expression of ACE gene polymorphisms in the concave and convex sides of the scoliotic curve in patients with AIS. We evaluated ACE gene expression in the multifidus muscles of the spine of 21 patients operated for AIS correction who had signs of asymmetric myopathy (worse in the concavity). Tissue samples were collected during corrective surgery. There was no significant difference in ACE gene expression in multifidus muscle samples from the two sides of the apex of the thoracic AIS deformity. There were also no differences in the expression of insertion/deletion polymorphisms.
\end{abstract}


Key words: Scoliosis; Idiopathic; Muscle; Polymorphism; Genetics; Adolescent

Trial Registration: Cross-sectional study. No registration needed due to absence of health care intervention involving human participants.

\section{INTRODUCTION}

Adolescent idiopathic scoliosis (AIS) consists of a lateral deviation of the spine with vertebral rotation (Kane et al., 1977) with the onset in the age range of 10 years, until reaching skeletal maturity (Wynne-Davies, 1968). Despite consistent efforts by the research and medical communities, the etiology and pathogenesis of idiopathic scoliosis in general, and specifically adolescent idiopathic scoliosis (AIS) remain unknown (Riseborough et al., 1973).

It has been suggested that idiopathic scoliosis is a primary and diffuse muscle disease, with a significant decrease in muscle fiber type II as well as myopathic alterations, as shown by histochemical and morphometric analysis using electron microscopy (Sahgal et al., 1983). Other muscle alterations include an increase in type I fibers in the convexity of the scoliotic curve associated with loss of type II fibers in the concavity (Fidler et al., 1974; Maffuli, 1989; Chagas et al., 1998); elevated intracellular concentrations of glycogen and lipids (Wong et al., 1977); structural changes in the sarcolemma and myotendineous junction (Kohsla et al., 1980; Ovalle et al., 1983); altered muscle enzyme activity (Cotic et al., 1983); and elevated intracellular calcium concentrations (Blatt et al., 1984). The histological changes in muscle fibers suggest a congenital origin for AIS (Wajchenberg et al., 2015), that include the development of central core myopathy, atrophy, necrosis, preponderance of type I fibers, perimisial and endomysial fibrosis and fatty proliferation more evident in the concavity of the deformity.

AIS more commonly afflicts female Caucasian individuals with a lanky body type. Previous work focused on the physical and radiological features of populations with these characteristics, assessing the behavior of the disease in families (Lonstein, 1994; Wajchenberg et al, 2005; Wajchenberg et al., 2012). Wise et al. (2000) made the first attempt to relate AIS to certain chromosomal regions, through genetic linkage studies in these families. Other genetic linkage and genome-wide association studies (GWAS) in different populations potentially implicated new chromosomal regions in AIS, such as 19p13.3 (Chan et al., 2002; Alden et al., 2006), 8q12 (Gao et al., 2007), Xq23-26.1 (Justice et al., 2003), 12p (Raggio et al., 2009), 18q (Gurnett er al., 2009) and 17p11 (Chen et al., 2009). Wajchenberg et al. (2010) investigated multiple cases within a single family, suggesting that possibly the failure in identifying a single chromosomal region linked to AIS is an indication that the disease is probably not monogenic.

Single nucleotide polymorphisms (SNPs) usually have no effect on cell function. However, many of them bear a high correlation with disease, drug action in cellular response, and physical performance (Wajchenberg et al., 2012). SNPs may also affect the function of certain tissues. Recent studies of genetic polymorphisms aimed at correlating certain genes with AIS, including MATN1 in region 1p35 (Chen et al., 2009), CHD7 in region 8q12.1 (Gao et al., 2007), IL (Auliza et al., 2007), MMP3 (Chen et al., 2009), DPP9 (Qui et al., 2008) and LBX1 (Takahashi et al., 2011). 
The angiotensin converting enzyme (ACE) gene, formed by 26 exons, is located in chromosome 17q23. Polymorphisms are related to the deletion (allele D) or insertion (allele I) of 287 base pairs in intron 16 (Wajchenberg et al., 2013; Luciano et al., 2016). ACE expression levels vary and depend on the presence of these alleles which affect blood supply especially in tissues with high aerobic demand such as the paravertebral muscles (Wajchenberg et al., 2013; Luciano et al., 2016; Almeida et al., 2010). In a genetic study of 25 members of the same family of an AIS patient, 19 individuals had polymorphisms (DD, $76 \%$ or ID, $24 \%$ ) of the ACE gene. The allele D was present in $88 \%$, and of allele I, of $12 \%$ (Wajchenberg et al., 2013).

The main objective of this study was to evaluate whether the ACE gene expression in the muscles of AIS patients is different in the concave or convex sides of the spinal curvature. Histological analysis in a previous study (Wajchenberg et al., 2015) unveiled severe muscle atrophy with fibrous and fatty proliferation of the muscles in the most affected concave side so we expected to find less expression in the concavity due to greater muscular involvement.

\section{MATERIAL AND METHODS}

\section{Study design, ethics and participants}

This cross-sectional study was conducted with a convenience sample composed of all patients with AIS consecutively admitted at a University Hospital in São Paulo, Brazil, for surgical treatment from May 2010 to June 2013. The Institutional Review Board of the Federal University of São Paulo / Hospital São Paulo (protocol 0043/10) approved the protocol and procedures, and a signed informed consent for the collection of tissue was mandatory for inclusion in this study.

All patients included had Cobb angles $>45$ degrees, and they underwent surgery for the correction of AIS with vertebral fusion and the use of synthesis material in the same hospital. Lumbar and thoracic vertebrae were approached posteriorly, with dissection by planes, placement of pedicular screws in strategic vertebrae and placement of titanium stems in the concavity and convexity for correction of the deformity and posterolateral arthrodesis, with bone graft.

\section{Tissue samples for biopsy}

We obtained tissues for polymerase chain reaction (PCR) analysis from the biopsies of the rotator muscles of the spinal curve apex, taken during surgery. We harvested the samples from the paraspinal muscles in the concave and convex sides of the scoliosis curve, which have usually significantly more fibrosis and fatty involution (Wajchenberg et al., 2015). Tissue samples were obtained during AIS surgery in a standardized method, using scissors and surgical tweezers. The harvesting was made in the apex of the scoliosis curve, both in the convex and in the concave sides, including the entire transverse section of the multifidus muscle, from its origin in the spinous process in the vertebral level above to the muscle insertion in the level below, the muscle was completely removed, from its origin to insertion, with size between 2 and 3 centimeters. Muscle biopsy followed the procedure described by Schmidt et al. (1988), and extracted samples were protected in gauze and 
refrigerated. Samples were immediately taken to the laboratory, where they were placed over a cork, embedded in gum tragacanth, and covered in talc. Samples were then immersed in liquid nitrogen for $20 \mathrm{~s}$, and the blocks were stored at $-80^{\circ} \mathrm{C}$.

\section{Genotyping}

We used PCR to identify the ACE I/D polymorphism. Briefly, we used primers (ECAS: 5'-CTGGAGACCACTCCCATCCTTTCT-3' and ECAR: 5'GATGTGGCCATCACATTCGTCAGAT-3') flanking the polymorphic region outside of the Alu insert in intron 16 to amplify by PCR a portion of the ACE gene. We analyzed the amplified product by gel electrophoresis to determine the presence or absence of I and D alleles. Because the D allele is preferentially amplified in heterozygotes, each DD genotype was confirmed by a second independent PCR with another primer pair (ECAint: 5'GTCTCGATCTCCTGACCTCGTG-3' and ECAS: 5' CTGGAGACCACTCCCATCCTTTCT-3') that amplified a sequence that was specific to the I allele (Wajchenberg et al., 2013; Luciano et al., 2016).

We used real-time PCR to evaluate the mRNA expression of the ACE gene in the tissues. For RNA extraction, we used the TRIZOL reagent (Invitrogen Corporation, California, USA), according to the manufacturer's specifications. Briefly, samples were left to stand at room temperature for 5 minutes after homogenization with TRIZOL. Subsequently, $200 \mathrm{uL}$ of chloroform were added and the tubes were vortexed for about 15 seconds each. After 3 minutes standing at room temperature, the samples were centrifuged at $12,000 \mathrm{~g}$ for $15 \mathrm{~min}$ at $4^{\circ} \mathrm{C}$. With the aid of an automatic pipettor, $100 \mathrm{uL}$ was withdrawn from the upper aqueous phase containing the RNA, and transferred to another tube. RNA was precipitated with $500 \mathrm{uL}$ of isopropanol, during a 10-minute incubation period at room temperature. Samples were then centrifuged at $12,000 \mathrm{~g}$ for $10 \mathrm{~min}$ and $4^{\circ} \mathrm{C}$ and the isopropanol was carefully removed. Salt was removed from Trizol with the addition of $1 \mathrm{ml}$ of $75 \%$ ethanol followed by centrifugation at $7000 \mathrm{~g}$ for $5 \mathrm{~min}$. at $4{ }^{\circ} \mathrm{C}$. All ethanol was removed and the tubes kept open to completely dry the pellets for approximately 10 minutes. Subsequently, the RNA was dissolved in RNAse-free water and the concentration and purity determined by absorbance at $260 \mathrm{~nm}$ (A260) and the A260/A280 ratio, respectively. The RNA integrity was assessed in $1 \%$ agarose gel in the presence of SYBR Safe DNA Gel Stain (10,000 x, Invitrogen), a fluorescent nucleic acid probe. The RNA was aliquoted and stored at $-80{ }^{\circ} \mathrm{C}$ until use.

RNA was totally reverse transcribed to complementary DNA (cDNA), using MMLV enzyme (Life Technologies, Invitrogen) according to the manufacturer's instructions. The cDNA was submitted to real time PCR in the 7500 Sequence Detection System (ABI Prism, Life Technologies) using the TaqMan Gene Expression Assay System (Life Technologies).

\section{Outcomes and analysis}

We analyzed the ACE gene expression and the genotype of the ACE gene polymorphism (II, ID and DD), and we compared gene expression in the multifidus muscle in the concave and convex sides of the spinal curvature. We present the results here descriptively. 


\section{Statistical analysis}

The SPSS statistical package version 22.0 (SPSS, Chicago, IL, USA) and GraphPad version 6.0 were used for statistical evaluation (GraphPad Software, San Diego, CA, USA). Data are expressed as means \pm SEM (standard errors of the mean). Given the sample size and the variable distribution, nonparametric tests were used. Data for three or more independent groups were analyzed using the Kruskal-Wallis test, and a multiple comparison post hoc test was used too (Dunn's test). A two-tailed p-value b 0.05 was chosen as the level of significance.

\section{RESULTS}

\section{Patients}

In the study period, a total of 21 female patients operated for AIS correction and were included in this study. They had a mean and median age of 14.8 and 14 years (Table 1). The mean Cobb angular value of the main thoracic curve was $68^{\circ}$ and $77.5^{\circ}$ in the thoracolumbar/lumbar curves.

Table 1. Age distribution, angular curve value, Lenke and King classification, and angiotensin I converting enzyme (ACE) genotype of patients with adolescent idiopathic scoliosis.

\begin{tabular}{|c|c|c|c|c|}
\hline Patient & Age (Years) & Angular Curve Value & Lenke and King classification & ACE genotype \\
\hline 1 & 13 & T1-T6 - 58\% T6-L1 - 90\% L1-L4 - $25^{\circ}$ & Lenke 2AN / King V & II \\
\hline 2 & 14 & $\mathrm{~T} 5-\mathrm{T} 10-52^{\circ} / \mathrm{T} 10-\mathrm{L} 4-64^{\circ}$ & Lenke $6 \mathrm{CN} / \mathrm{King} \mathrm{I}$ & II \\
\hline 3 & 12 & $\mathrm{~T} 6-\mathrm{T} 12-56^{\circ} / \mathrm{L} 1-\mathrm{L} 528^{\circ}$ & Lenke 1 / King II & ID \\
\hline 4 & 12 & $\mathrm{~T} 5-\mathrm{T} 11-62^{\circ} / \mathrm{T} 12-\mathrm{L} 4-55^{\circ}$ & Lenke $1 \mathrm{C}+/$ King II & ID \\
\hline 5 & 13 & $\mathrm{~T} 3-\mathrm{T} 11-52^{\circ} / \mathrm{T} 11-\mathrm{L} 4-43^{\circ}$ & Lenke $1 \mathrm{CN} / \mathrm{King}$ II & ID \\
\hline 6 & 24 & $\mathrm{~T} 4-\mathrm{T} 11-57^{\circ} / \mathrm{T} 11-\mathrm{L} 4-75^{\circ}$ & Lenke 6C- / King I & ID \\
\hline 7 & 14 & $\mathrm{~T} 5-\mathrm{L} 1-50^{\circ} / \mathrm{L} 1-\mathrm{L} 4-36^{\circ}$ & Lenke $1 \mathrm{BN} / \mathrm{King}$ II & ID \\
\hline 8 & 15 & $\mathrm{~T} 3-\mathrm{T} 6-32^{\circ} / \mathrm{T} 7-\mathrm{L} 1-50^{\circ} / \mathrm{L} 1-\mathrm{L} 525^{\circ}$ & Lenke $2 \mathrm{AN} / \mathrm{King} \mathrm{V}$ & ID \\
\hline 9 & 17 & $\mathrm{~T} 1-\mathrm{T} 3-18^{\circ} / \mathrm{T} 4-\mathrm{T} 11-63^{\circ} \mathrm{T} 12-\mathrm{L} 4-34^{\circ}$ & Lenke $1 \mathrm{BN} /$ King II & ID \\
\hline 10 & 15 & $\mathrm{~T} 5-\mathrm{T} 11-70^{\circ} / \mathrm{T} 12-\mathrm{L} 4-54^{\circ}$ & Lenke $3 \mathrm{CN} /$ King II & ID \\
\hline 11 & 21 & $\mathrm{~T} 4-\mathrm{T} 9-76^{\circ} / \mathrm{T} 9-\mathrm{L} 3-56^{\circ}$ & Lenke $3 \mathrm{CN} / \mathrm{King}$ II & II \\
\hline 12 & 15 & $\mathrm{~T} 1-\mathrm{T} 314^{\circ} / \mathrm{T} 4-\mathrm{T} 11-56^{\circ} / \mathrm{T} 11-\mathrm{L} 4-60^{\circ}$ & Lenke $1 \mathrm{CN} / \mathrm{King}$ II & ID \\
\hline 13 & 13 & $\mathrm{~T} 3-\mathrm{T} 11-55^{\circ} / \mathrm{T} 11-\mathrm{L} 4-40^{\circ}$ & Lenke $2 \mathrm{CN} / \mathrm{King}$ II & ID \\
\hline 14 & 14 & $\mathrm{~T} 4-\mathrm{T} 1153^{\circ} / \mathrm{T} 11-\mathrm{L} 452^{\circ}$ & Lenke 1C- / King II & ID \\
\hline 15 & 15 & T7-L3 - $88^{\circ}$ & Lenke $1 \mathrm{CN} / \mathrm{King}$ IV & ID \\
\hline 16 & 14 & $\mathrm{~T} 4-\mathrm{T} 10-60^{\circ} / \mathrm{T} 10-\mathrm{L} 4-83^{\circ}$ & Lenke 6CN / King I & DD \\
\hline 17 & 13 & $\mathrm{~T} 1-\mathrm{T} 4-56^{\circ} / \mathrm{T} 5-\mathrm{T} 8-115^{\circ} / \mathrm{T} 12-\mathrm{L} 4-45^{\circ}$ & Lenke 4CN /King II & DD \\
\hline 18 & 13 & $\mathrm{~T} 5-\mathrm{T} 12-97^{\circ} / \mathrm{T} 12-\mathrm{L} 4-45^{\circ}$ & Lenke 3BN / King II & DD \\
\hline 19 & 16 & $\mathrm{~T} 2-\mathrm{T} 5-48^{\circ} / \mathrm{T} 6-\mathrm{T} 11-75^{\circ} / \mathrm{T} 12-\mathrm{L} 4-48^{\circ}$ & Lenke 4CN / King II & DD \\
\hline 20 & 15 & $\mathrm{~T} 3-\mathrm{T} 11 \mathrm{D}-46^{\circ} / \mathrm{T} 11-\mathrm{L} 4-20^{\circ}$ & Lenke 1AN / King III & DD \\
\hline 21 & 14 & C5-T5 - 58 / T6-L1 - 90 / L1-L5 - $43^{\circ}$ & Lenke $2 \mathrm{C}+/$ King V & DD \\
\hline
\end{tabular}

\section{ACE analysis}

The frequency of each ACE genotype in the group was identified as 6/21 ) type DD, 12/21 type ID and 3/21 type II (Table 1 ). 


\section{ACE expression in concave and convex sides of the spinal curve}

There were no significant differences in the tissue expression of ACE in the concave (CV) and convex (CX) sides of the muscle samples evaluated (Figure 1). The expression of the different polymorphisms of the ACE gene (II, ID and DD; Figure 2) was also similar between convex and concave sides.

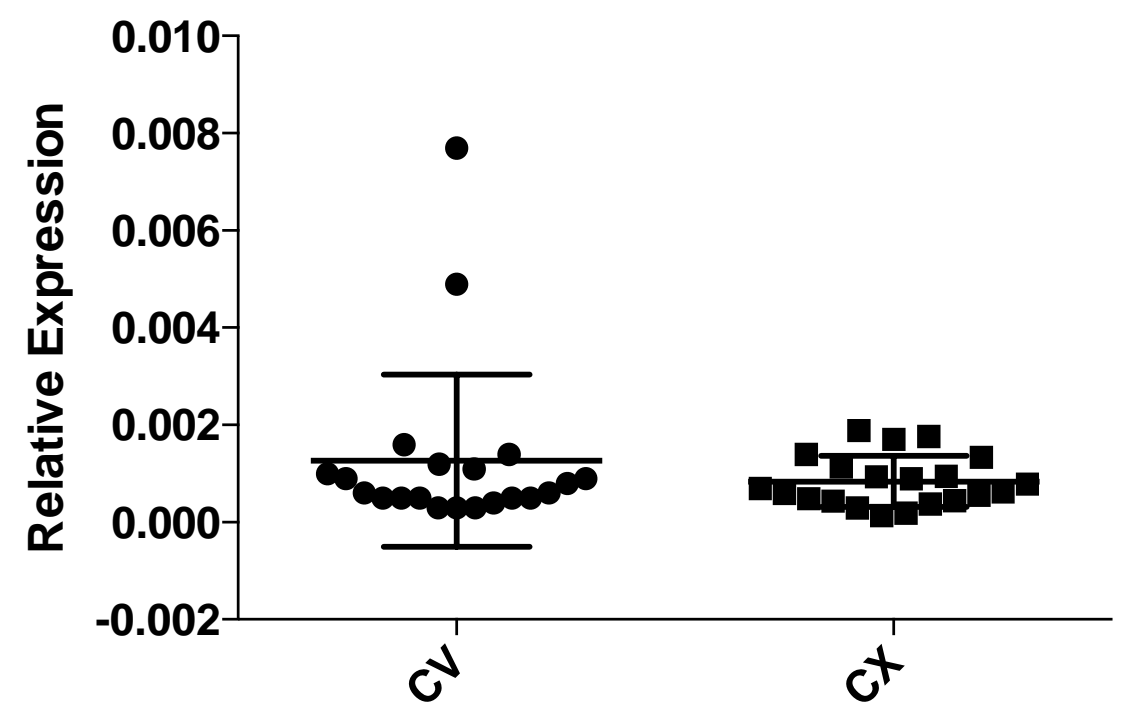

Figure 1. Tissue expression of the angiotensin I - converting enzyme (ACE) gene in the concave (CV) and convex (CX) sides of the multifidus muscles of patients with adolescent idiopathic scoliosis.

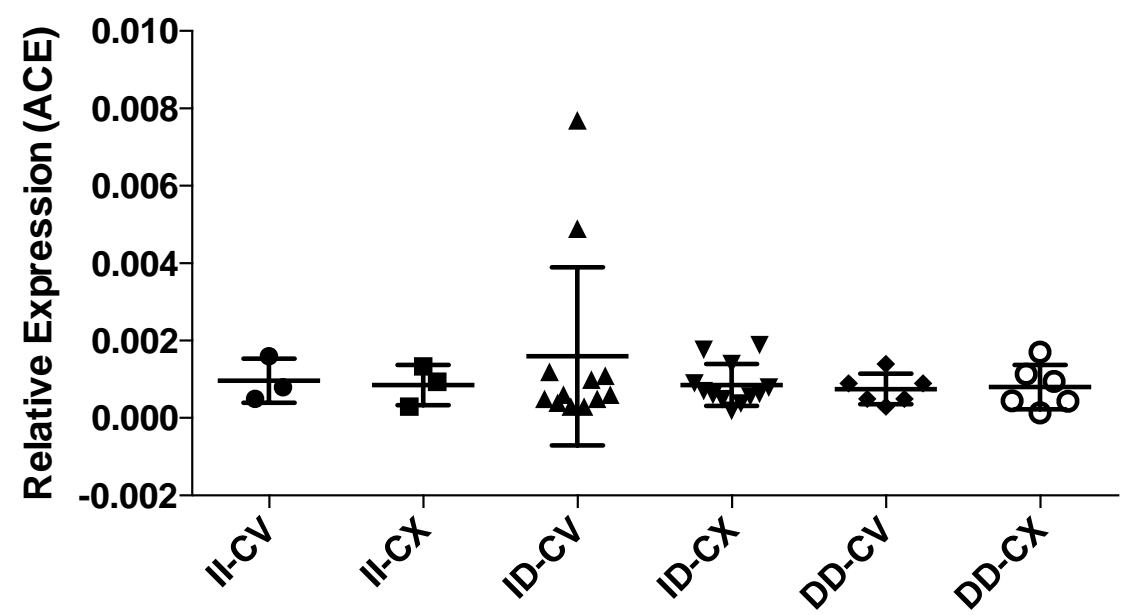

Figure 2. Tissue expression of angiotensin I - converting enzyme (ACE) gene polymorphisms (II, ID and DD) in the concave $(\mathrm{CV})$ and convex $(\mathrm{CX})$ sides of the multifidus muscles of 21 patients with adolescent idiopathic scoliosis. 


\section{DISCUSSION}

The etiology of AIS remains uncertain, despite numerous efforts to ascertain the cause of this disease. Population studies were performed to find associations of the condition with specific genes, but determining which individuals actually have AIS poses an obstacle for most of this work (Wajchenberg et al., 2010), because the Scoliosis Research Society includes all patients with curves $>10^{\circ}$ - which could be debatable, due to the difficult clinical differentiation of an "unaffected" patient with $9^{\circ}$ of curvature, and an affected patient, with $10^{\circ}$ or $11^{\circ}$ (which could still be due to a simple, non pathological asymmetry). Diagnosis of AIS is made based on clinical and radiological examination. However, an abnormal curvature in the spine in the frontal plane, associated with rotation, and measurements of the Cobb angle do not suffice to determine whether an individual may be considered as affected (Wajchenberg et al., 2010; Wajchenberg et al., 2013). Therefore, the best methods to investigate the cause of AIS include analyses of severely affected patients, with higher scoliotic curves (Wajchenberg et al., 2010; Wajchenberg et al., 2013).

We agree with Grauers et al. (2016) that a genetic approach focused on finding common variants (GWAS) will not reveal rare variants; on the other hand linkage studies of a family may identify disease causing variants in that specific family but these findings might not be applicable in most patients. Wajchenberg et al. (2010) using a genetic linkage study in a family with multiple affected individuals, could not isolate the genetic region responsible for AIS. The major difficulty faced by IS genetic studies is phenotypic and genetic heterogeneity. Gorman et al. (2012) found in reviewing 50 studies that IS genetic studies were overrepresented by underpowered studies that suggested an association, and then by underpowered replication studies that could not confirm or refute the original hypotheses.

Histological analysis in a previous study unveiled severe muscle atrophy with fibrous and fatty proliferation of the muscles in the most affected concave side but also in the convex side of the curves (Wajchenberg et al., 2015). This previous publication reported the existence of central core, congenital, myopathy. We chose to continue the work by investigating ACE gene polymorphisms in the same patients, in an attempt to determine a gene expression profile for each patient in the muscles previously evaluated through histological analysis. This choice was not based on the belief that the mere presence of a specific polymorphism may have a causal relationship with disease development, as previously discussed by several authors. We also believe it is important to evaluate the expression of said polymorphisms in tissues involved with AIS.

If a relation were observed, the finding could pave the for future work connecting ACE to the condition. Theoretically, a reduction in ACE activity associated with the expression of the I allele could promote the greater muscle endurance capacity observed in healthy individuals (Zhang et al., 2003). This enzyme is directly involved in the production of angiotensin II, a vasoconstrictor peptide, and in the degradation of bradykinin. Thus, high ACE activity, associated with the D allele, may reduce the uptake of glucose and muscle blood flow, which could damage muscle groups with a predominance of aerobic, type I fibers, such as the multifidus muscle and the erector spinae bundle (Rigat et al., 1990). Altogether, this body of work justifies the study of this polymorphism in the context of AIS.

In the present study, we assessed ACE gene expression in the multifidus muscles of the spine, on both sides of the apex of the deformity. However, no significant differences 
were found between the concave and convex sides for each genotype, or among genotypes. This lack of differences may be due to the action of other tissue mechanisms that minimize the effect of ACE polymorphisms in the tissue evaluated (Zhang et al., 2003). After all, we expected to find less expression in the concavity due to greater muscular involvement.

Limitations of this study include a lack of normal controls. In future studies, potentially normal, muscle groups from the same patients could be analyzed to provide a comparison of ACE polymorphism expression in normal and affected tissues. A larger sample could flush out subtle differences in the expression of the polymorphisms. Additionally, the serum expression of ACE could also be used as a comparison with the muscle tissue expression. Finally, we did not measure ACE activity in the spinal muscles. It should be remembered that AIS is a multifactorial disease that probably involves many genes and environmental factors. Therefore, the activity of many other genes and polymorphisms should be assessed in the same affected individuals.

\title{
CONCLUSIONS
}

There was no significant difference in ACE gene expression in multifidus muscles taken from the two sides of the apex of the AIS deformity. There was also no difference in the expression of insertion/deletion polymorphisms.

\section{LIST OF ABBREVIATIONS}

\author{
ACE - Angiotensin I - converting enzyme \\ AIS - Adolescent Idiopathic Scoliosis \\ Allele I - insertion \\ Allele D - deletion \\ IS - Idiopathic scoliosis \\ $\mathrm{CV}$ - concave \\ CX - convex
}

\section{DECLARATIONS}

Ethics approval and consent to participate: The Institutional Review Board of the Federal University of Sao Paulo and Sao Paulo Hospital (protocol 0043/10) aproved the protocol and procedures, and a signed (written) informed consent for the collection of tissue was mandatory for inclusion in this study.

Consent for publication: 'Not Applicable'

Availability of data and material: All data generated or analysed during this study are included in this published article [and its supplementary information files].

Competing interests: The authors do not have conflicts of interest.

\section{ACKNOWLEDGMENTS}

The authors thank Patricia Logullo for assistance in editing the text. 


\section{FUNDING}

This study was performed with funding from Fundação de Apoio a Pesquisa do Estado de Sao Paulo (FAPESP).

\section{AUTHORS CONTRIBUTIONS}

MW was the coordinator and the major responsible for the manuscript, DEM assisted in the planning, bibliographical survey and writing of the manuscript, RPL assisted in the collection of the samples and in the preparation of the analyzed muscles, RCA participated in the research planning, BS did the histological analysis along with MW, ABSO and EBP participated in the planning of the research, SSA did analysis of the polymorphisms, their measurement, statistical analysis and revised the manuscript. FF Guided the project and participated in research planning.

\section{REFERENCES}

Alden KJ, Marosy B, Nzegwu N, Justice CM, et al. (2006). Idiopathic scoliosis: Identification of candidate regions on chromosome 19p13. Spine. 31(16): 1815-19.

Almeida SS, Barros CC, Moraes MR, Russo FJ, et al. (2010). Plasma Kallikrein and Angiotensin I-converting enzyme $\mathrm{N}$ - and C-terminal domain activities are modulated by the insertion/deletion polymorphism. Neuropeptides. 44(2): $139-43$.

Auliza L, Papaleo P, Polla E, Angelini F, et al. (2007). Association between IL-6 and MMP-3 gene polymorphisms and adolescent idiopathic scoliosis. Spine. 32(24): 2000-2.

Blatt JM, Rubin E, Botin GC and Heller M (1984). Impaired calcium pump activity in idiopathic scoliosis. Possible etiological role of a membrane defect. Orth. Trans. 8: 143.

Chagas JCM, Schmidt B, Puertas EB, Oliveira CEAS, et al. (1998). Histochemical study of lumbar rotator muscles in patients with adolescent idiopathic scoliosis. Rev. Bras. Ortop. 33(2): 111-18.

Chan V, Fong GCY, Kuk KDK, Yip B, et al. (2002). A genetic locus for adolescent idiopathic scoliosis linked to chromosome 19p13.3. Am. J. Hum. Genet. 71: 401-6.

Chen Z, Tang NLS, Cao X, Qiao D, et al. (2009). Promoter polymorphism of matrilin-1 gene predisposes to adolescent idiopathic scoliosis in a Chinese population. Eur. J. Hum. Genet. 17: 525-32.

Cotic V, Bizjak F and Turk V (1983). The activity of proteinases of the paravertebral muscles in idiopathic scoliosis. "Scoliosis and Kyphosis", ed. M.Pecina, Dubrovnik, p 250.

Fidler MW, Jowett RL and Troup JDG (1974). Histochemical study of the function of multifidus in scoliosis. "Scoliosis and Muscle", ed. Zorab PA, London, p 184-92.

Gao X, Gordon D, Zhang D, Browne R, et al. (2007). CHD7 gene polymorphisms are associated with susceptibility to idiopathic scoliosis. Am. J. Hum. Genet. 80: 957-65.

Gorman KF, Julien C and Moreau A (2012). The genetic epidemiology of idiopathic scoliosis. European Spine J. 21(10): 1905-1919

Grauers A, Einarsdottir E and Gerdhem P (2016). Genetics and pathogenesis of idiopathic scoliosis. Scoliosis Spinal Disord. 11: 45.

Gurnett CA, Alaee F, Bowcock A, Kruse L, et al. (2009). Genetic linkage localizes an adolescent idiopathic scoliosis and pectus excavatum gene to chromosome 18 q. Spine. 34(2): E94-100.

Justice CM, Miller NH, Marosy B, Zhang J, et al. (2003). Familial idiopathic scoliosis: evidence of an X-linked susceptibility locus. Spine. 28(6): 589-94.

Kane WJ (1977). Newer knowledge of scoliosis: a tribute to John H. Moe. M.D. Clin. Orthop. 126: 2-3.

Kohsla S, Tredwell SJ, Day B, Shinn SL, et al. (1980). An ultrastructural study of the multifidus muscle in progressive idiopathic scoliosis. J. NeurSci. 46: 12-21.

Lonstein JE (1994). Adolescent idiopathic scoliosis. The Lancet. 344: 1407-12.

Luciano RP, Wajchenberg M, Almeida SS, Amorim CEN, et al. (2016). Genetic ACE I/D and ACTN3 R577X polymorphisms and adolescent idiopathic scoliosis. Genet. Mol. Res. 15 (4): 1- 9.

Maffuli N (1989). Histochemical and physiological studies in idiopathic scoliosis. Italian J. Orthop. Trauma. 16(1): 6171. 
Ovalle WK and Tredwell SJ (1983). The paraspinalmyotendinous junction: a possible morphological marker for idiopathic scoliosis. Orth. Trans. 7: 4.

Qui Xs, Tang NLS, Yeung HY, Qiu Y, et al. (2008). Association study between adolescent idiopathic scoliosis and the DPP9 gene, which is located in the candidate region identified by linkage analysis. Postgrad. Med. J. 84: 498-501.

Raggio CL, Giampietro PF, Dobrin S, Zhao C, et al. (2009). A novel locus for adolescent idiopathic scoliosis on chromosomes 12p. J. Orthop. Res. 27: 1366-72.

Rigat B, Hubert C, Alhenc-Gelas F, Cambien F, et al. (1990). An insertion/deletion polymorphism in the angiotensin Iconverting enzyme gene accounting for half the variance of serum enzyme levels. J. Clin. Invest. 86(4): 1343-6.

Riseborough EJ and Wynne-Davies R (1973). A genetic survey of idiopathic scoliosis in Boston, Massachusetts. J. Bone Joint. Surg. Am. 55-A: 974-82.

Sahgal V, Shah A, Flanagan N, Schaffer M, et al. (1983). Morphologic and morphometric studies of muscle in idiopathic scoliosis. Acta Orthop. 54: 242-51.

Salehi LB, Mangino M, De Serio S, De Cicco D, et al. (2002). Assignment of a locus for autosomal dominant idiopathic scoliosis (IS) to human chromosome 17p11. Hum. genet. 111: 401-4.

Schmidt B, Gabbai A, Oliveira A, et al. (1988). Biópsia muscular, nova metodologia: a dança dos "farabeufs. Rev. Bras. Ortop. 23: 21-26.

Takahashi Y, Kou I, Takahashi A, Johnson TA, et al. (2011). A genome-wide association study identifies common variants near LBX1 associated with adolescent idiopathic scoliosis. Nat. Genet. 43: 1237-40

Wajchenberg M, Lazar M, Cavaçana N, Martins DE, et al. (2010) Genetic aspects of adolescent idiopathic scoliosis in a family with multiple affected members: a research article. Scoliosis. 7: 5:7.

Wajchenberg M, Luciano RP, Araújo RC, Martins DE, et al. (2013). Polymorphism of the ACE gene and the alfa Actinin-3 gene in the adolescent idiopathic scoliosis. Acta Ortop. Bras. 21(3): 170-4.

Wajchenberg M, Martins DE, Luciano RP, Puertas EB, et al. (2015). Histochemical analysis of paraspinal rotator muscles from patients with adolescent idiopathic scoliosis. Medicine. 94(8): e598.

Wajchenberg M, Martins DE and Puertas EB. (2012). Aspectos genéticos da escoliose idiopática do adolescente. Coluna/Columna. 11(3): 234-36.

Wajchenberg M, Puertas EB and Zatz M (2005). Estudo da prevalência da escoliose idiopática do adolescente em pacientes brasileiros. Coluna/Columna. 4(3): 127-31

Wise CA, Barnes R, Gillum J, Herring JA, et al. (2000) Localization of susceptibility to familial idiopathic scoliosis. Spine. 25: 2372-80.

Wong YC, Yau ACMC, Low WD, Chin NY, et al. (1977). Ultrastructural changes in the back muscles of idiopathic scoliosis. Spine. 2: 251-60.

Wynne-Davies R. Familial (idiopathic) scoliosis: a family survey. (1968). J. Bone Joint. Surg. Br. 50-B: 24-30.

Zhang B, Tanaka H, Shono N, Miura S, et al. (2003). The I allele of the angiotensine-converting enzyme gene is associated with an increase percentage of slow-twitch type I fibers in human a skeletal muscle. Clin. Genet. 63: 139 -44 . 